\title{
Feeding ecology of demersal elasmobranchs from the shelf and slope off the Balearic Sea (western Mediterranean)
}

\author{
MARIA VALLS, ANTONI QUETGLAS, FRANCESC ORDINES and JOAN MORANTA \\ Instituto Español de Oceanografía, Centre Oceanogràfic de les Balears, Moll de Ponent s/n, 07015 Palma, Spain. \\ E-mail: maria.valls@ba.ieo.es
}

\begin{abstract}
SUMMARY: The feeding ecology of eight demersal elasmobranchs, three sharks (Etmopterus spinax, Scyliorhinus canicula and Galeus melastomus) and five batoids (Myliobatis aquila, Leucoraja naevus, Raja polystigma, R. miraletus and $R$. clavata), from the Balearic Sea (western Mediterranean) was analyzed. For each species, the diet and feeding habits were characterized by depth strata using quantitative indices such as diet overlap, diet breadth and prey diversity. Diet variation with size and depth were also tested for the most abundant species. For shelf-living species, natantian and reptantian crustaceans together with teleosts were the most important preys. On slope bottoms, euphausiids were the preferential prey for S. canicula and G. melastomus, while E. spinax fed mainly on cephalopods. The most specialist and generalist diet corresponded to $G$. melastomus living on the upper slope and $S$. canicula from the continental shelf, respectively. High overlap was found between all the skates on the continental shelf and the sympatric sharks S. canicula and G. melastomus on the slope. Significant overlap was also found between $S$. canicula and $R$. clavata on the continental shelf. Size was found to significantly affect the diet of $S$. canicula, G. melastomus and R. clavata, whereas depth affected exclusively $S$. canicula.
\end{abstract}

Keywords: Elasmobranch, batoid, shark, feeding habits, diet overlap, niche breadth, Mediterranean.

RESUMEN: ECOLOGÍA ALIMENTARIA DE ELASMOBRANQUIOS DEMERSALES DE PLATAFORMA Y TALUD EN AGUAS DE LAS ISLAS BALEARES (MEDiterRáNeo OCCIDENTAL). - Se estudia la ecología alimentaria de ocho elasmobranquios demersales, tres tiburones (Etmopterus spinax, Scyliorhinus canicula y Galeus melastomus) y cinco rayas (Myliobatis aquila, Leucoraja naevus, Raja polystigma, R. miraletus y $R$. clavata), del mar Balear (Mediterráneo Occidental). Para cada especie se caracterizó la dieta y la estrategia alimentaria por estratos de profundidad mediante diferentes índices cuantitativos. También se analizó la variación intraespecífica de la dieta con la talla y la profundidad en las especies más abundantes. Las presas más frecuentes en especies de la plataforma continental fueron los peces y los crustáceos natantia y reptantia. En aguas del talud las presas principales de $S$. canicula y G. melastomus fueron los eufausiáceos, mientras que E. spinax consumió preferentemente cefalópodos. Las especies con la dieta más especializada y más generalista fueron G. melastomus del talud superior y S. canicula de la plataforma costera, respectivamente. En aguas de la plataforma se detectó solapamiento de dieta entre todas las especies de batoideos, así como entre $S$. canicula y $R$. clavata; el solapamiento fue significativo también entre $S$. canicula y G. melastomus del talud. Se observaron cambios ontogénicos en la dieta de S. canicula, G. melastomus y $R$. clavata, mientras que la única especie que mostró cambios de dieta con la profundidad fue $S$. canicula.

Palabras clave: elasmobranquio, batoideo, tiburón, estrategia alimentaria, solapamiento de dieta, amplitud de nicho, Mediterráneo.

\section{INTRODUCTION}

Trophic relationships are fundamental to understanding biological interactions in animal communities and how they respond to human exploitation. Elasmobranchs are top predators playing an important role in the marine ecosystems with a top-down control on the size and dynamics of many species (Wetherbee and Cortes, 2004). Globally, there is increasing evidence that elasmobranchs are more affected than teleosts by fishing exploitation (Stevens et al., 2000). Insular areas from the western and central Mediterranean sustain 
elasmobranch assemblages with higher diversity and abundance than adjacent mainland areas (Massutí and Moranta, 2003).

Despite the importance of feeding relationships to understand the food structure and dynamics of marine ecosystems, little is known about the feeding ecology of most elasmobranchs (Heithaus, 2004; Wetherbee and Cortes, 2004). This is especially true for batoids, which have received considerably less attention than sharks at a worldwide level (Ishihara, 1990; Motta, 2004). Research on trophic relationships among elasmobranch sympatric species is also scarce in the western Mediterranean, where selachian feeding habits have been studied exclusively with regard to single species and groups of two or three species with similar ecological roles or habitat distribution (Macpherson, 1980, Carrason et al., 1992; Saidi et al., 2009). Furthermore, few studies have focussed on the feeding ecology of batoids individual species in the Mediterranean Sea (Jardas et al., 2004; Romanelli et al., 2007; Saglam and Bascinar, 2008).

In the present paper we analyze the diet, feeding habits and trophic interactions for three selachians (Etmopterus spinax, Scyliorhinus canicula and Galeus melastomus) and five batoids (Myliobatis aquila, Leucoraja naevus, Raja polystigma, $R$. miraletus and $R$. clavata) from waters off the Balearic Islands (western Mediterranean).

\section{MATERIALS AND METHODS}

The elasmobranch species were taken from the fishery-independent MEDITS bottom trawl surveys conducted around the Balearic Islands (Fig. 1) in early summer from 2007 to 2009. Both sampling scheme and gear (GOC-73) were the same as those used throughout the Mediterranean in the MEDITS programme (Bertrand, 2002). A total of 141 hauls were performed during daylight hours between 45 and $755 \mathrm{~m}$ depth. Whenever possible, ten individuals of each elasmobranch species from each haul were separated and their total length, weight and sex were noted. Fresh stomach contents were identified on board to the lowest possible taxonomic level and then all prey items were counted and their volume was measured with a calibrated device used in previous studies (Olaso et al., 1998).

The diet of each elasmobranch species was quantified using the following indices: 1) frequency of occurrence $(\% \mathrm{~F})$, percentage of stomachs with a specific type of prey in relation to the total number of stomachs containing food; 2) numerical $(\% \mathrm{~N})$ and volumetric $(\% \mathrm{~V})$ composition, expressed as the percentage contribution of each prey to the whole content, in number or volume respectively; 3 ) index of relative importance $(\mathrm{IRI}=\% \mathrm{~F}(\% \mathrm{~N}+\% \mathrm{~V})$, which was standardized following \%IRI=(IRI/ $\sum$ IRI $) \times 100($ Cortes, 1997); 4) vacuity index $(v)$, the percentage of empty stomachs; and 5) diet breadth, which was calculated using the Levin's standardized index:

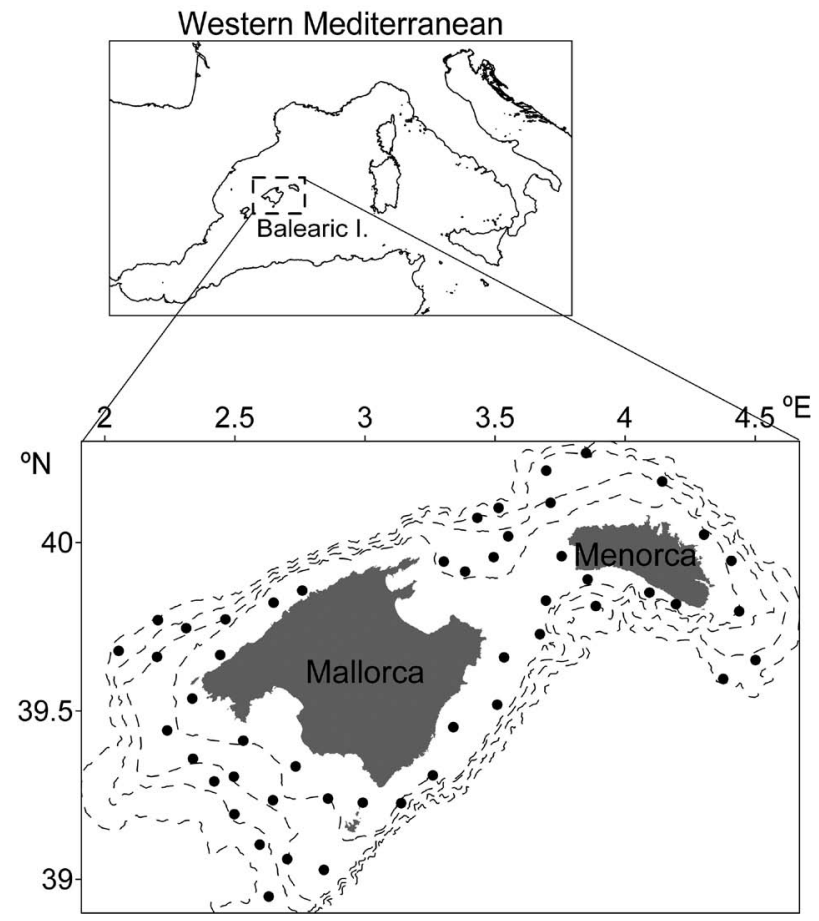

FIG. 1. - Map of sampling sites of the eight elasmobranch species taken in the Balearic Islands (western Mediterranean). The 100, 200,500 and $800 \mathrm{~m}$ isobaths are shown.

$$
B_{i}=\frac{1}{n-1}\left(\frac{1}{\sum_{j} p_{i j}^{2}}-1\right),
$$

where $p_{i j}$ is the proportion of diet of predator $i$ that is made up of prey $j$ and $n$ is the number of prey categories. This index ranges from 0 to 1 , low values indicating diets dominated by a few prey items (specialist predators) and higher values indicating generalist diets (Krebs, 1999); and 6) species diversity in both prey number $\left(\mathrm{H}_{\mathrm{n}}\right)$ and prey volume $\left(\mathrm{H}_{\mathrm{v}}\right)$ calculated using the Shannon-Wiener index.

To standardize data and to facilitate diet comparisons and analyses, the following twelve major prey categories were established: Polychaeta, Sipuncula, Gastropoda, Bivalvia, Cephalopoda, Euphausiacea, Amphipoda, Isopoda, Mysidacea, Crustacea Reptantia, Crustacea Natantia and Teleostea. Prey categories with frequency of occurrence lower than $3 \%$ and unidentifiable remains were excluded from these analyses. Diet overlap between species was calculated using the Schoener index (Hurlbert, 1978), which ranges from 0 (no overlap) to 1 (complete overlap), with values greater than 0.6 representing a significant overlap (Sala and Ballesteros, 1997; Wallace, 1981). In order to compare exclusively coexisting species, all indexes characterizing the diet were analyzed separately for the following four bathymetric strata described in the study area (Ordines et al., 2011): 1) continental shelf (CS: 45-180 m); 2) shelf-break (SB: 180-330 m); 3) upper slope (US: 330-495 m); and 4) middle slope (MS: 495-750 m). 
TABLE 1. - General information and diet composition (standardized index of relative importance, \%IRI) of eight elasmobranch species caught at different bathymetric strata (CS, continental shelf; SB, shelf-break; US, upper slope; MS, middle slope) in the Balearic Sea (western Mediterranean). N, sample size; TL, total length; WR, weight range; DR, depth range; $v$, vacuity index; $\mathrm{H}_{\mathrm{n}}$, $\mathrm{H}_{\mathrm{v}}$ : Shannon-Wiener diversity in number and volume respectively; and $\mathrm{B}_{\mathrm{i}}$, Levin's niche breadth. Values in brackets are the number of taxa in the twelve major taxonomic groups of prey (see Supplementary material Appendix 1). R.pol., R. polystigma; M.aqu., M. aquila; L.nae., L. naevus; R.mir., R. miraletus.

\begin{tabular}{|c|c|c|c|c|c|c|c|c|c|c|c|c|c|}
\hline & \multirow{2}{*}{$\begin{array}{l}\text { R.pol. } \\
\text { CS }\end{array}$} & \multirow{2}{*}{$\begin{array}{c}\text { M.aqu. } \\
C S\end{array}$} & \multirow{2}{*}{$\begin{array}{l}\text { L.nae. } \\
\text { CS }\end{array}$} & \multirow{2}{*}{$\begin{array}{l}\text { R.mir. } \\
\text { CS }\end{array}$} & \multicolumn{3}{|c|}{ R. clavata } & \multicolumn{3}{|c|}{ S. canicula } & \multicolumn{2}{|c|}{ G. melastomus } & \multirow{2}{*}{$\begin{array}{l}\text { E. spinax } \\
{ }_{M S}\end{array}$} \\
\hline & & & & & CS & & US & CS & & US & & MS & \\
\hline $\mathrm{N}$ & 15 & 23 & 27 & 31 & 26 & 48 & 6 & 766 & 66 & 6 & 170 & 167 & 46 \\
\hline TL & $28-45$ & $1-1$ & & & & $18-77$ & $64-$ & $11-53$ & $14-46$ & & 14 & & $11-47$ \\
\hline WR ( & $91-546$ & $514-4201$ & $59-864$ & $66-421$ & $25-4005$ & $27-2612$ & $1445-4458$ & $11-470$ & $20-336$ & $23-390$ & $7-106$ & $2-628$ & $5-514$ \\
\hline $\mathrm{DR}(\mathrm{n}$ & $63-172$ & $51-63$ & $107-174$ & $58-83$ & $52-174$ & $249-256$ & $355-691$ & $53-174$ & $249-256$ & $355-444$ & $355-450$ & 593-755 & $597-755$ \\
\hline ta & $1.17(1)$ & 8.07 (1) & $0.29(1)$ & $0.05(1)$ & 0.08 (1) & & & $22.10(2)$ & $12.53(1)$ & $0.5(1)$ & & & $0.26(1)$ \\
\hline Sipunc & & $1.63(2)$ & & & & & & $2.07(2)$ & & & & & \\
\hline Gas & $0.5(1)$ & $26.3(3)$ & & $0.08(1)$ & $0.59(8)$ & $0.15(1)$ & & $2.38(6)$ & & & & & \\
\hline Biv & & $6.28(1)$ & & & $<0.01(1)$ & & & $<0.01$ (1) & & & & & \\
\hline la & $0.5(1)$ & 0.13 (1) & & $0.08(1)$ & $0.59(6)$ & 0.15 & & $2.36(4)$ & $0.60(1)$ & $0.23(1)$ & 0.0 & (8) & $64.26(4)$ \\
\hline & & & & & $5.13(2)$ & $1.19(1)$ & & $2.34(2)$ & $72.38(2)$ & $77.64(2)$ & $92.59(2)$ & $42.97(2)$ & $0.90(2)$ \\
\hline & $1.10(1)$ & $0.09(1)$ & $2.78(1)$ & $3.87(1)$ & 0.04 (1) & 0.24 (1) & & $0.81(2)$ & & $0.52(1)$ & $0.32(2)$ & $0.15(2)$ & \\
\hline & $7.22(1)$ & & $1.08(1)$ & 0.0 & $3.83(1)$ & $1.19(1)$ & & $0.51(1)$ & 1.93 & $0.95(1)$ & & $0.01(1)$ & $0.37(1$ \\
\hline My & $6.63(2)$ & & $2.66(1)$ & $0.36(1)$ & $2.55(2)$ & $10.49(2)$ & & $7.40(2)$ & $0.21(1)$ & $0.21(2)$ & $<0.01(1)$ & $0.01(2)$ & \\
\hline & $3.35(3)$ & 81.9 & $1.32(2)$ & $54.88(2)$ & $29.39(18)$ & $12.96(10)$ & & $34.71(19)$ & & $0.53(5)$ & & $0.08(3)$ & 0.0 \\
\hline Natantia & $67.97(4)$ & $1.10(2)$ & $50.88(5)$ & $34.78(5)$ & $27.19(8)$ & $31.84(5)$ & $12.87(3)$ & $8.62(11)$ & $5.74(4)$ & $2.03(7)$ & 2.60 (7) & 14.19 (10) & $8.54(4)$ \\
\hline Teleost & $13.51(2)$ & & $40.80(2)$ & $5.88(3)$ & 31.08 (18) & $41.82(9)$ & 45.87 (3) & $17.85(16)$ & $5.46(3)$ & $16.68(3)$ & $4.42(5)$ & $25.61(9)$ & $25.25(4)$ \\
\hline ems & 15 & 15 & 13 & 15 & 63 & 31 & 11 & 79 & 19 & 25 & 21 & 45 & 16 \\
\hline$v(\%)$ & 0 & 4.3 & 11.1 & 0 & 9 & 10.4 & 0 & 20 & 33. & 18.3 & 27. & 19.8 & 45.7 \\
\hline $\mathrm{H}_{\mathrm{n}}^{\prime}$ & 3.22 & 2.18 & 3.05 & 2.83 & 3.24 & 3.9 & 3.27 & 4.10 & 2. & 2.0 & 2.0 & 3.50 & 3.44 \\
\hline $\mathrm{H}_{\mathrm{v}}{ }^{\mathrm{n}}$ & 3.2 ? & 2.5 & 2.2 & & 4.9 & 3. & 2.8 & 4.3 & 3. & 3.1 & 2.8 & 3.93 & 2.97 \\
\hline$B_{\mathrm{i}}$ & 0.49 & 0.26 & 0.36 & 0.31 & 0.47 & 0.49 & 0.23 & 0.67 & 0.49 & 0.47 & 0.17 & 0.43 & 0.28 \\
\hline
\end{tabular}

Diet overlap, niche breadth and diet diversities were calculated using Ecological Methodology software version 7.0 (Krebs, 1999).

Intra-specific trends in the diet related to predator size (total length in $\mathrm{cm}$ ), and depth $(\mathrm{m})$ of the most abundant species (S. canicula, G. melastomus and $R$. clavata) were studied applying partial canonical correspondence analysis (pCCA) using CANOCO (ter Braak and Smilauer, 1998). In the pCCA procedure, one explanatory variable (size or depth in this case) was set as a covariable, which allowed the effect of the other one to be tested after the variation explained by the covariable had been factored out. The significance of the explanatory variables was assessed by means of the Monte Carlo permutation-based test. Before the design of the model, the interactions between explanatory variables were analyzed and found to be non-significant.

\section{RESULTS}

General information for the eight species studied (e.g. sample size, size and weight range and depth range), the diet composition considering the twelve main major prey categories, and the dietary indexes used (e.g. vacuity, diversity, niche breadth) are shown in Table 1. Total sample sizes were rather unbalanced, ranging from the 15 individuals of $R$. polystigma to about 900 of $S$. canicula. The number of different prey items ranged from 11 in $R$. clavata from the US to 79 in $S$. canicula from the CS. Considering depth strata, sample sizes ranged from 6 individuals of $R$. clavata caught on the US to $766 \mathrm{~S}$. canicula individuals from the MS. With the exception of the batoids M. aquila and $R$. clavata, all other species had maximum sizes smaller than $65 \mathrm{~cm}$ length. Whereas $S$. canicula and $R$. clavata inhabited all depth strata, the other batoid and shark species were caught exclusively on the shelf and slope, respectively. The percentage of empty stomachs was clearly higher in selachian (18-46\%) than in batoid species $(0-11 \%)$. Globally, the highest dietary diversity was found on the CS, where $S$. canicula and $R$. clavata showed the highest values in terms of numbers (4.10) and volume (4.55) respectively (Table 1). The lowest diversity in numbers was found on the US $(\sim 2.1$ for both $G$. melastomus and S. canicula) but the lowest in weight occurred on the CS (2.3 for L. naevus). The most generalist and specialist diets were found in $S$. canicula from the $\mathrm{CS}\left(\mathrm{B}_{i}=0.67\right)$ and G. melastomus from the US $\left(\mathrm{B}_{i}=0.17\right)$. The rest of species had values ranging from 0.26 to 0.49 , indicating moderate levels of feeding specialization.

The diet composition of each species is summarized in this paragraph, taking into account both the main prey groups (Table 1) and the lowest identified taxonomic levels (Supplementary material Appendix 1). Beginning with the batoids, natantian crustaceans (68\%IRI) followed at some distance by teleosts (13\%IRI), isopods (7\% IRI) and mysids (7\%IRI) were the most important preys of $R$. polystigma. The diet of $M$. aquila was based on anomuran crustaceans (63\%IRI) such as Dardanus arrosor (18\%IRI) and unidentified Paguridae species (11\%IRI), molluscs (26\%IRI) and polychaetes ( $8 \%$ IRI). The diet of L. naevus was almost exclusively based on natantian crustaceans (51\%IRI), mainly Solenocera membranacea (15\%IRI), and teleosts $(41 \%$ IRI). Brachyuran (55\%IRI) and natantian (35\%IRI) crustaceans, followed at some distance by 
TABLE 2. - Diet overlap (Schoener index, SI) for coexisting elasmobranch species on the continental shelf, shelf break, upper and middle slope of the western Mediterranean. Biologically significant diet overlaps (SI > 0.6) are in bold.

\begin{tabular}{|c|c|}
\hline Species & SI \\
\hline \multicolumn{2}{|l|}{ Continental shelf } \\
\hline R. clavata vs $M$. aquila & 0.28 \\
\hline R. miraletus vs $R$. clavata & 0.73 \\
\hline R. miraletus vs $M$. aquila & 0.47 \\
\hline L. naevus vs $M$. aquila & 0.16 \\
\hline L. naevus vs R. miraletus & 0.65 \\
\hline L. naevus vs $R$. clavata & 0.74 \\
\hline$R$. polystigma vs $R$. clavata & 0.76 \\
\hline$R$. polystigma vs $R$. miraletus & 0.65 \\
\hline R. polystigma vs L. naevus & 0.83 \\
\hline S. canicula vs $M$. aquila & 0.57 \\
\hline S. canicula vs $R$. clavata & 0.71 \\
\hline S. canicula vs $R$. miraletus & 0.58 \\
\hline S. canicula vs L. naevus & 0.51 \\
\hline S. canicula vs $R$. ploystigma & 0.59 \\
\hline \multicolumn{2}{|l|}{ Shelf break } \\
\hline S. canicula vs $R$. clavata & 0.42 \\
\hline \multicolumn{2}{|l|}{ Upper slope } \\
\hline S. canicula vs G. melastomus & 0.73 \\
\hline S. canicula vs R. clavata & 0.37 \\
\hline G. melastomus vs R. clavata & 0.31 \\
\hline \multicolumn{2}{|l|}{ Middle slope } \\
\hline E. spinax vs G. melastomus & 0.67 \\
\hline
\end{tabular}

TABLE 3. - Results of the partial canonical correspondence analysis (pCCA) testing the effects of predator size (total length, $\mathrm{cm}$ ) and depth (m) on the volumetric contribution of the diets of the sharks Scyliorhinus canicula and Galeus melastomus and the skate Raja clavata. The percentage of variance explained (VE), the F-ratio, and the $P$-value are shown (ns: non-significant effect).

\begin{tabular}{lcccccc}
\hline Predator species & \multicolumn{3}{c}{ Size } & & \multicolumn{3}{c}{$\begin{array}{c}\text { Depth } \\
\text { F-ratio }\end{array}$} & $P$ \\
& VE & F-ratio & $P$ & VE & F-rata \\
\hline S. canicula & 4.12 & 4.25 & $<0.01$ & 7.42 & 7.65 & $<0.01$ \\
G. melastomus & 9.63 & 8.37 & $<0.01$ & 2.13 & 1.88 & n.s. \\
R. clavata & 11.54 & 15.64 & $<0.01$ & 1.40 & 1.85 & n.s. \\
\hline
\end{tabular}

teleosts (6\%IRI), were the most important preys of $R$. miraletus. The skate $R$. clavata preyed on teleosts (31\%IRI), natantian (27\%IRI) and reptantian (29\%IRI) crustaceans on the CS, but on teleosts (42\%IRI) and natantians (32\%IRI) on the SB; teleosts (46\%IRI) and reptantians $(41 \% \mathrm{IRI})$ were the main preys on the US, although these values must be taken with caution owing to the small sample size $(\mathrm{N}=6)$. Concerning the sharks, S. canicula preyed on reptantians (35\%IRI), polychaetes (22\%IRI) and teleosts (18\%IRI) on the CS; euphausiids were the most important prey on both the SB (72\%IRI) and US (78\%IRI), followed by polychaetes (12\%IRI) and teleosts (17\%IRI), respectively. The catshark G. melastomus preyed almost exclusively on euphausiids on the US (93\% IRI), but on a mixture of euphausiids (43\%IRI), teleosts (26\%IRI), cephalopods $(16 \%$ IRI) and natantians (14\%IRI) on the MS. Finally, the diet of E. spinax consisted primarily of cephalopods (64\%IRI) and teleosts (25\%IRI), followed at some distance by natantian crustaceans (9\%IRI).

Diet overlap was biologically significant $(>0.6)$ in 9 of the 19 coexisting species (Table 2). In other four cases, however, the overlap remained close to the cutoff value of significance (0.51-0.59). Diet overlap was significant among different pairs of skate species and between the shark S. canicula and R. clavata on the CS. Overlap also existed between the sharks $S$. canicula and G. melastomus on the US and between E. spinax and G. melastomus on the MS.

Considering intra-specific trends for the three most abundant species, size was found to significantly affect the diet of all of them, whereas depth affected exclusively the shark S. canicula (Table 3 ). There existed a gradient of increasing prey size with increasing predator size in all three species, ranging from small-sized
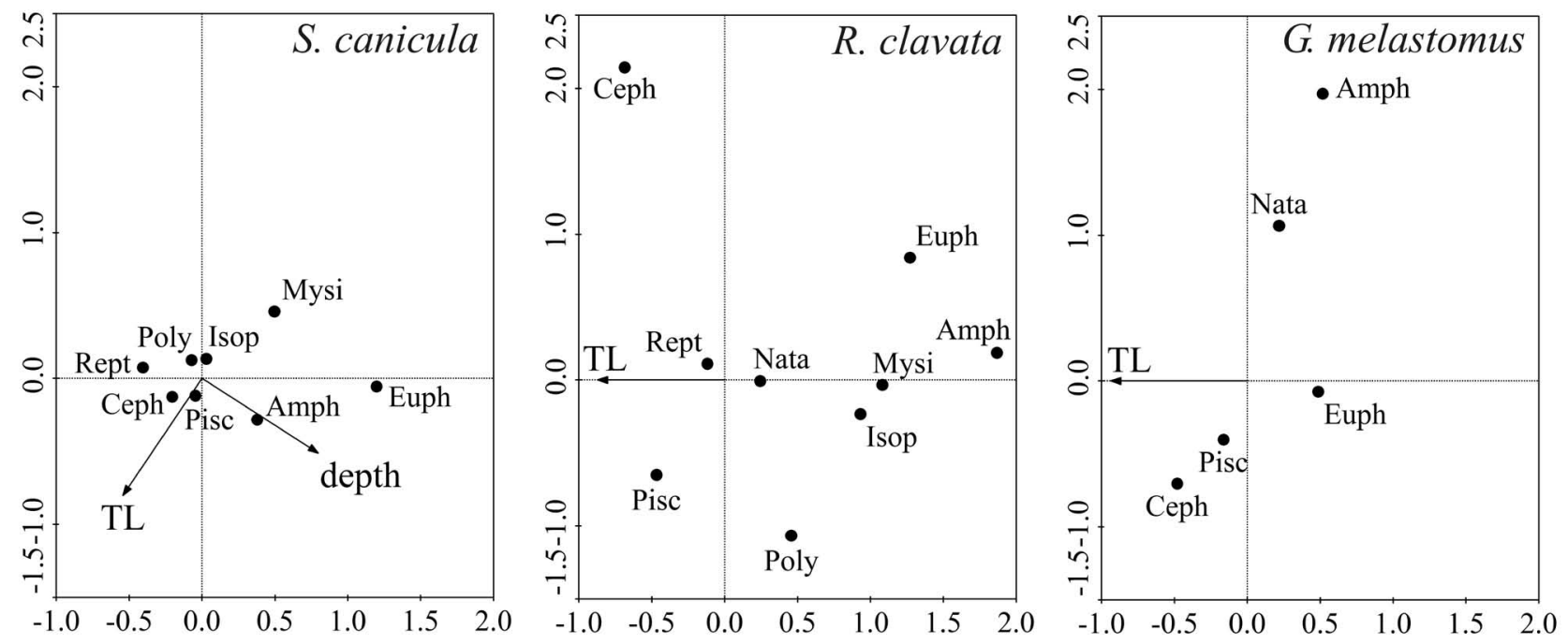

FIG. 2. - Partial canonical correspondence analysis (pCCA) biplots of the explanatory variables predator size (total length, cm) and depth of capture (in m) and nine different prey categories for the sharks Scyliorhinus canicula and Galeus melastomus and the skate Raja clavata. Euph, euphausiids; Amph, amphipods; Mysi, mysids; Isop, isopods; Poly, polychaetes; Nata, natantia; Rept, reptantia; Ceph, cephalopods; Pisc, pisces. 
preys such as amphipods, euphausiids and mysids to large-sized preys such as cephalopods and teleosts (Fig. 2). In the case of the bathymetric effect on S. canicula, the separation along the depth axis seems to be related to preferences for prey such as polychaetes and reptantian crustaceans in the shallow populations and euphausiids in the deeper populations.

\section{DISCUSSION}

To our knowledge, this is the first study in the Mediterranean dealing with the trophic ecology (e.g. diet composition, diet diversity, niche breadth, diet overlap) of such a large number of elasmobranchs, since we have analyzed data of the most abundant demersal species from our study area. In total, three shark species (Etmopterus spinax, Scyliorhinus canicula and Galeus melastomus), and five batoid species (Myliobatis aquila, Leucoraja naevus, Raja polystigma, R. miraletus and $R$. clavata) inhabiting the shelf (CS: shelf and SB: shelf break) and the slope (US: upper slope and MS: middle slope) were analyzed. Other studies in the Mediterranean analyzed at most three elasmobranch species (Macpherson, 1980).

The vacuity index was clearly higher in sharks (18$46 \%$ ) than in batoids (0-10\%), which could be related to the well-known decrease in trophic resources with increasing depth (Carrasson et al., 1992; Olaso et al., 2005). Fittingly, the shark E. spinax, which only inhabits the deepest stratum (MS), had nearly half of their stomachs empty. The fact that $E$. spinax feeds preferentially on cephalopods, which in general have high nutritional values and low non-edible remains (Boyle and Rodhouse, 2005), may also influence such a high vacuity index. With the only exception of $S$. canicula from the CS, which showed the most generalist diet (0.67), and G. melastomus from the US, which showed the most specialist behaviour (0.17), all other species had niche breadth values between 0.26 and 0.49 that might be associated with moderate levels of specialization. Such moderate levels could be related to the high species richness and biomasses of shelf benthic ecosystems from the Balearic Islands (Massutí and Reñones, 2005; Ordines and Massutí, 2009). Lower niche breadths on the slope than on the shelf might also be related to the already mentioned decrease in trophic resources with depth. As pointed out by Carrasson et al. (1992), the decrease in the number of prey per stomach and the trophic diversity with depth are indicative of the increasing resource scarceness along the depth gradient in the western Mediterranean. On the CS, diet overlap was biologically significant among all the batoid species, except M. aquila, and between the skate $R$. clavata and the shark $S$. canicula. The lack of significant dietary differences among comparably-sized shelf skates suggests that inter-specific resource competition was not intense (Bizzarro et al., 2007). High values of overlap do not necessarily imply competition, except when resources are in short supply (Macpherson, 1977;
Cartes, 1998). The coexistence between species with similar trophic habits and a narrow niche breadth might be due to the abundance of food resources (Collwell and Futuyma, 1971). As mentioned above, this would be the case on the rich shelf bottoms of our study area. Otherwise, species that are spatially segregated are not driven to differentiate their diets and may easily converge in the use of resources overlapping areas (Ross, 1977). Elasmobranch species from the Balearic Islands showed different optimum depths (Ordines et al., 2011), which could indicate a sort of fine-tuned bathymetric segregation, though they coexisted on shelf and slope bottoms.

In accordance with previous studies carried out in both the Mediterranean (Romanelli et al., 2007; Saglam and Bascinar, 2008) and the Atlantic (Ellis et al., 1996; Gomes et al., 1998; Farias et al., 2006), the dominant prey taxa in all the batoid species, except $M$. aquila, were natantian crustaceans and teleosts. However, the diet of M. aquila was highly specialized in anomuran crustaceans and non-cephalopod molluscs (mainly bivalves), two prey groups that, with the exception of anomurans in $S$. canicula, were barely present in the rest of species; $M$. aquila was also characterized by being the only species that did not prey on teleosts and by the moderate importance of polychaetes. Such important differences would explain the lack of diet overlap between M. aquila and the rest of the elasmobranch species. In general, other authors mentioned the same food preferences for M. aquila in the Mediterranean (Azouz and Capapé, 1971; Capapé and Quignard, 1974; Capapé, 1976; Jardas et al., 2004) but differed with regard to such a specialized diet based in anomuran crustaceans. The diet of $R$. miraletus differed slightly from that of the other skates, as it preyed mainly on a mixture of brachyuran crabs and natantian crustaceans and displayed a narrow niche breadth. In accordance with previous studies (Farias et al., 2006; Saglam and Bascinar, 2008), the skate $R$. clavata based its diet on teleosts and reptantian and natantian crustaceans, showing no trend with depth.

The shark S. canicula inhabiting the CS showed the highest diversity of all species-strata, having a diet composed of a mixture dominated by reptantian crustaceans, polychaetes, teleosts and natantians. Prey diversity, however, decreased with depth, mainly because the shark changed to a diet based on euphausiids in deeper waters. Secondary preys were polychaetes and teleosts on the SB and US, respectively. To our knowledge, the importance of polychaetes in the diet of $S$. canicula has not been reported previously. Polychaetes were also found in all the batoids analyzed, but they only constituted accessory preys. In the Cantabrian Sea, Serrano et al. (2003) found that polychaetes preyed by $S$. canicula belonged to surface and subsurface mobile families. As Olaso et al. (1998) pointed out, referring to the presence of subsurface species in the diet of $S$. canicula, high consumption rates of polychaetes might indicate the availability of endobenthic preys that are 
exposed to predation because of the physical effects of trawling.

The diets of the catsharks S. canicula and G. melastomus overlapped on the US, where both species preyed mainly on euphausiids. The shark G. melastomus displays a marked bathymetric segregation of populations in the study area, with recruits and adults inhabiting the US and MS, respectively (Massutí and Moranta, 2003). Consequently, competition for resources on the US, namely euphausiids, occurs between adults of $S$. canicula and recruits of G. melastomus. However, it is also possible that competition is lessened by a sort of size selection of preys owing to the marked size differences between the small-sized G. melastomus and the adults of $S$. canicula. The occurrence of euphausiids in the diet of a large number of species inhabiting the SB and US may be due to the high abundance of these organisms in those strata (Cartes et al., 2009).

The diets of the sharks E. spinax and G. melastomus, which were the only species coexisting on the MS, showed both similarities and notable differences. The similarities were that both species had comparatively low to moderate values of natantian crustaceans (8-14\%IRI) and high values of teleosts (25\%IRI). The differences appeared in the relative importance of euphausiids and cephalopods, which showed an inverse pattern in the two species: while cephalopods were the most important prey (64\%IRI) and euphausiids only vestigial (1\%IRI) for E. spinax, values in G. melastomus were inverted (16 and 43\%IRI, respectively). Given that both species showed significant diet overlap, this inverse pattern would be a mechanism to lessen competition on the MS. In agreement with this, Macpherson (1980) found that the diet overlap between these two species was significant for all size classes and seasons in the western Mediterranean. Both sharks consumed mesopelagic preys that were typical inhabitants of the Benthic Boundary Layer (BBL) (Angel and Boxshall, 1990), such as myctophids, euphausiids (e.g. Meganycthyphanes norvegica) and cephalopods (e.g. Histioteuthis spp.). These mesopelagic preys would be caught when the BBL remains close to the bottom, indicating the high dependence of slope demersal elasmobranchs on the pelagic ecosystem (Bizzarro et al., 2007; Rinewalt et al., 2007 ). A high dietary overlap between these two species was also reported in the Cantabrian Sea (Preciado et al., 2009) but, in contrast with the preference of $E$. spinax for cephalopods in our samples, that population preyed mainly on euphausiids.

The three most abundant elasmobranch species $(R$. clavata, G. melastomus and S. canicula) showed ontogenetic variations in diet. The trend was the same in the three species, with small individuals preying mainly on crustaceans but changing to a diet based on fishes in large-sized individuals. Such ontogenetic shifts have already been reported in other areas for both the two catsharks (Macpherson, 1980; Olaso et al., 2005) and the skate (Holden and Tucker, 1974; Ellis et al., 1996; Saglam and Bascinar, 2008). However, results of some studies focusing on $R$. clavata do not agree with this trend, such as the shift from benthic shrimps to pelagic crabs reported by Farias et al. (2006) and the lack of differences with size found by Morato et al. (2003). Ontogenetic shifts in diet are generally related to higher metabolic requirements of larger individuals (Carlson et al., 2004) or to resource partitioning (Werner and Gilliam, 1984). The metabolic explanation would apply to $S$. canicula, because juvenile and adult populations live on different bathymetric strata in the Mediterranean (D'Onghia et al., 1995; Massutí and Moranta, 2003). Given that there is no bathymetric segregation of size classes either in $R$. clavata or in the populations of G. melastomus living on the MS in our study area (Massutí and Moranta, 2003), the observed ontogenetic shift might be a way of avoiding intraspecific competition.

To conclude, the present work is a comprehensive study on the feeding ecology of the most abundant demersal elasmobranchs, including both shark and batoid species, from an insular area geographically separated from the mainland in the western Mediterranean. Our results represent an important step forward in the knowledge of the trophic interactions among these elasmobranchs, but further studies of aspects not dealt with here, such as seasonal variations in diet, prey availability and diet of the coexisting teleost community, are needed to improve the assessment of the role played by these species on the marine food webs from this area.

\section{ACKNOWLEDGEMENTS}

The authors wish to thank all the participants who took part in the MEDITS surveys, and particularly J.L. Gutierrez Zabala and M. Torres, who participated in the stomach contents analyses. We also acknowledge the financial support of the Instituto Español de Oceanografía and the European Commission for the MEDITS surveys.

\section{REFERENCES}

Angel, M.V. and G.A. Boxshall. - 1990. Life in the Benthic Boundary-Layer - Connections to the Mid-Water and Sea-Floor. Philos. T. Roy. Soc. A., 331: 15-28.

Azouz, J. and C. Capapé. - 1971. Les relations alimentaires entre les Sélaciens et le zoobenthos des côtes nord de la Tunisie. Bull. Inst. Natl. Sci. Tech. Oceanogr. Pêche Salammbo, 2: 121-130.

Bertrand, J.A. - 2002. Mediterranean marine demersal resources: The Medits international trawl survey (1994-1999) - Foreword. Sci. Mar., 66: 5-7.

Bizzarro, J.J., H.J. Robinson, C.S. Rinewalt and D.A. Ebert. -2007. Comparative feeding ecology of four sympatric skate species off central California, USA. Environ. Biol. Fish., 80: 197-220.

Boyle, P.R. and P. Rodhouse. - 2005. Cephalopods: Ecology and fisheries. Oxford, UK.

Capapé, C. - 1976. Etude du régime alimentaire de l'aigle de mer, Myliobatis aquila (L. 1758) des côtes tunisiennes. J. Cons. Int. Explor. Mer., 37: 29-35.

Capapé, C. and J.P. Quignard. - 1974. Dimorphisme sexuel et observations biologiques sur Myliobatis aquila (L. 1758). Contribution à l'étude systématique du genre Myliobatis, Cuvier, 1817. Ann. Mus. Civ. St. Nat. Genova, 80: 1-27.

Carlson, J.K., K.J. Goldman and C.G. Lowe. - 2004. Metabolism, 
energetic demand, and endothermy. In: J.C. Carrier, J.A. Musick and M.R. Heithaus (eds.), Biology of Sharks and Their Relatives, pp. 203-224. CRC Press, Boca Raton.

Carrasson, M., C. Stefanescu and J.E. Cartes. - 1992. Diets and Bathymetric Distributions of 2 Bathyal Sharks of the Catalan Deep-Sea (Western Mediterranean). Mar. Ecol. Prog. Ser. 82: 21-30.

Cartes, J.E. - 1998. Feeding strategies and partition of food resources in deep-water decapod crustaceans (400-2300 m). J. Mar. Biol. Ass. U.K., 78: 509-524.

Cartes, J.E., M. Hidalgo, V. Papiol, E. Massuti and J. Moranta. 2009. Changes in the diet and feeding of the hake Merluccius merluccius at the shelf-break of the Balearic Islands: Influence of the mesopelagic-boundary community. Deep-Sea Res Part I., 56: 344-365.

Collwell, R.K. and D.J. Futuyma. - 1971. On the measurement of niche breadth and overlap. Ecology, 52: 567-576.

Cortes, E. - 1997. A critical review of methods of studying fish feeding based on analysis of stomach contents: Application to elasmobranch fishes. Can. J. Fish. Aquat. Sci., 54: 726-738.

D'Onghia, G., A. Matarrese, A. Tursi and L. Sion. - 1995. Observations on the Depth Distribution Pattern of the Small-Spotted Catshark in the North Aegean Sea. J. Fish Biol., 47: 421-426.

Ellis, J.R., M.G. Pawson and S.E. Shackley. - 1996. The comparative feeding ecology of six species of shark and four species of ray (Elasmobranchii) in the north-east Atlantic. J. Mar. Biol. Ass. U.K. 76: 89-106.

Farias, I., I. Figueiredo, T. Moura, L.S. Gordo, A. Neves and B. Serra-Pereira. - 2006. Diet comparison of four ray species (Raja clavata, Raja brachyura, Raja montagui and Leucoraja naevus) caught along the Portuguese continental shelf. Aquat. Living Resour., 19: 105-114.

Gomes, T.M., E. Sola, M.P. Gros, G. Menezes and M.R. Pinho. - 1998. Trophic relationships and feeding habits of demersal fishes from the Azores: importance to multispecies assessment. ICES J. Mar. Sci., 35:7-21.

Heithaus, M.R. - 2004. Predator - Prey interactions. In: Carrier J.C., Musick J.A., Heithaus, M.R. (eds.), Biology of Sharks and Their Relatives, pp. 487-521. CRC Press, Boca Raton.

Holden, M.J. and R.N. Tucker. - 1974. Food of Raja clavata Linnaeus 1758, Raja montagui Fowler 1910, Raja naevus Mulle and Henle 1841 and Raja brachyura Lafont 1873 in British Waters. J. Cons., 35: 189-193.

Hurlbert, S.H. - 1978. Measurement of Niche Overlap and Some Relatives. Ecology, 59: 67-77.

Ishihara, H. - 1990. The skates and rays of the western North Pacific: an overview of their fisheries, utilization, and classification. In Pratt H.L., Gruber S.H., Taniuchi T. (eds.), Elasmobranches as living resources: Advances in the biology, ecology, systematics and the status of the fisheries, pp. 485-497. NOAA Tech. Rep.90.

Jardas, I., M. Santic and A. Pallaoro. - 2004. Diet composition of the eagle ray, Myliobatis aquila (Chondrichthyes : Myliobatidae), in the eastern Adriatic Sea. Cybium, 28: 372-374.

Krebs, C.J. - 1999. Ecological Methodology. 2nd. ed. A. Wesley Longman, New York.

Macpherson, E. - 1977. Estudio sobre las relaciones tróficas en peces bentónicos de la costa catalana. $\mathrm{PhD}$ thesis, Univ. Barcelona.

Macpherson, E. - 1980. Régime alimentaire de Galeus melastomus Rafinesque, 1810, Etmopterus spinax (L., 1788) et Scymnorhinus licha (Bonnaterre, 1788) en Mediterranée Occidentale. Vie Milieu, 30: 139-148.

Massutí, E. and J. Moranta. - 2003. Demersal assemblages and depth distribution of elasmobranchs from the continental shelf and slope off the Balearic Islands (western Mediterranean). ICES J. Mar. Sci., 60: 753-766.

Massutí, E. and O. Reñones. - 2005. Demersal resource assemblages in the trawl fishing grounds off the Balearic Islands (western Mediterranean). Sci. Mar., 69: 167-181.

Morato, T., E. Sola, M.P. Gros and G. Menezes. - 2003. Diets of thornback ray (Raja clavata) and tope shark (Galeorhinus galeus) in the bottom longline fishery of the Azores, northeastern Atlantic. Fish. Bull., 101: 590-602.

Motta, P.J. - 2004. Prey capture behavior and feeding mechanics of elasmobranchs. In: J.C. Carrier, J.A. Musick and M.R. Heithaus (eds.), Biology of Sharks and Their Relatives, pp. 165-202. CRC Press, Boca Raton.

Olaso, I., F. Velasco and N. Perez. - 1998. Importance of discarded blue whiting (Micromesistius poutassou) in the diet of lesser spotted dogfish (Scyliorhinus canicula) in the Cantabrian Sea. ICES J. Mar. Sci., 55: 331-341.

Olaso, I., F. Velasco, F. Sánchez, A. Serrano, C. Rodríguez-Cabello and O. Cendrero. - 2005. Trophic relation of lesser spotted catshark (Scyliorhinus canicula) and blackmouth catshark (Galeus melastomus) in the Cantabrian Sea. J. Northwest Atl. Fish. Soc., 35: 481-494.

Ordines, F. and E. Massutí. - 2009. Relationships between macroepibenthic communities and fish on the shelf grounds of the western Mediterranean. Aquat. Conserv., 19: 370-383.

Ordines, F., E. Massutí, J. Moranta, A. Quetglas, B. Guijarro and K. Fliti. - 2011. Balearic Islands vs. Algeria: two nearby western Mediterranean elasmobranchs populations with different oceanographic scenarios and fishing histories. Sci. Mar., 75: 707-717.

Preciado, I., J.E. Cartes, A. Serrano, F. Velasco, I. Olaso, F. Sánchez and I. Frutos. - 2009. Resource utilization by deep-sea sharks at the Le Danois Bank, Cantabrian Sea, north-east Atlantic Ocean. J. Fish. Biol., 75: 1331-1355.

Rinewalt, C.S., D.A. Ebert and G.M. Cailliet. - 2007. Food habits of the sandpaper skate, Bathyraja kincaidii (Garman, 1908) off central California: seasonal variation in diet linked to oceanographic conditions. Environ. Biol. Fish., 80: 147-163.

Romanelli, M., A. Colasante, U. Scacco, I. Consalvo, M.G. Finoia and M. Vacchi. - 2007. Commercial catches, reproduction and feeding habits of Raja asterias (Chondrichthyes: Rajidae) in a coastal area of the Tyrrhenian Sea (Italy, northern Mediterranean). Acta Adriat., 48: 57-71.

Ross, S.T. - 1977. Patterns of resource partitioning in searobins (Pisces: triglidae). Copeia. 561-571.

Saglam, H. and N.S. Bascinar. - 2008. Feeding ecology of thornback ray (Raja clavata Linnaeus, 1758) on the Turkish coast of the south-eastern Black Sea. Mar. Biol., 4: 451-457.

Saidi, B., M.N. Bradai and A. Bouain. - 2009. Reproductive biology and diet of Mustelus punctulatus (Risso, 1826) (Chondrichthyes: Triakidae) from the Gulf of Gabes, central Mediterranean Sea. Sci Mar., 73(2): 249-258.

Sala, E. and E. Ballesteros. - 1997. Partitioning of space and food resources by three fish of the genus Diplodus (Sparidae) in a Mediterranean rocky infralittoral ecosystem. Mar. Ecol. Prog. Ser., 152: 273-283.

Serrano, A., F. Velasco and I. Olaso. - 2003. Polychaete annelids in the diet of demersal fish from the southern shelf of the Bay of Biscay. J. Mar. Biol. Ass. U.K., 83: 619-623.

Stevens, J.D., R. Bonfil, N.K. Dulvy and P.A. Walker. - 2000. The effects of fishing on sharks, rays, and chimaeras (chondrichthyans), and the implications for marine ecosystems. ICES J. Mar. Sci., 57: 476-494.

ter Braak C.J.F. and P. Smilauer. - 1998. CANOCO reference manual and User's Guide to Canoco for Windows: Software for Canonical Community Ordination. Microcomputer Power, Ithaca, New York.

Wallace, R.K. - 1981. An assessment of diet-overlap indexes. Trans. Am. Fish. Soc., 110: 72-76.

Werner, E.E. and J.F. Gilliam. - 1984. The Ontogenetic Niche and Species Interactions in Size Structured Populations. Annu. Rev. Ecol. Syst., 15: 393-425.

Wetherbee, B.M. and E. Cortes. - 2004. Food consumption and feeding habits. In: J.C. Carrier, J.A. Musick and M.R. Heithaus (eds.), Biology of Sharks and Their Relatives, pp. 225-246. CRC Press, Boca Raton.

Scient. ed.: E. Massutí.

Received March 23, 2010. Accepted March 3, 2011.

Published online July 13, 2011.

This is a contribution to 13th European Elasmobranch Association Conference (Palma, 19-22 Novembre 2009)

\section{SUPPLEMENTARY MATERIAL}

The following Appendix is available through the web page http://www.icm.csic.es/scimar/supplm/sm75n4633sm.pdf

APPENDIX 1. - Diet composition to the lowest possible taxon of eight elasmobranch species (five skates and three sharks) from the Balearic Islands (western Mediterranean). 
Feeding ecology of demersal elasmobranchs from the shelf and slope off the Balearic Sea (western Mediterranean)

MARÍA VALLS, ANTONI QUETGLAS, FRANCESC ORDINES and JOAN MORANTA

Supplementary material 


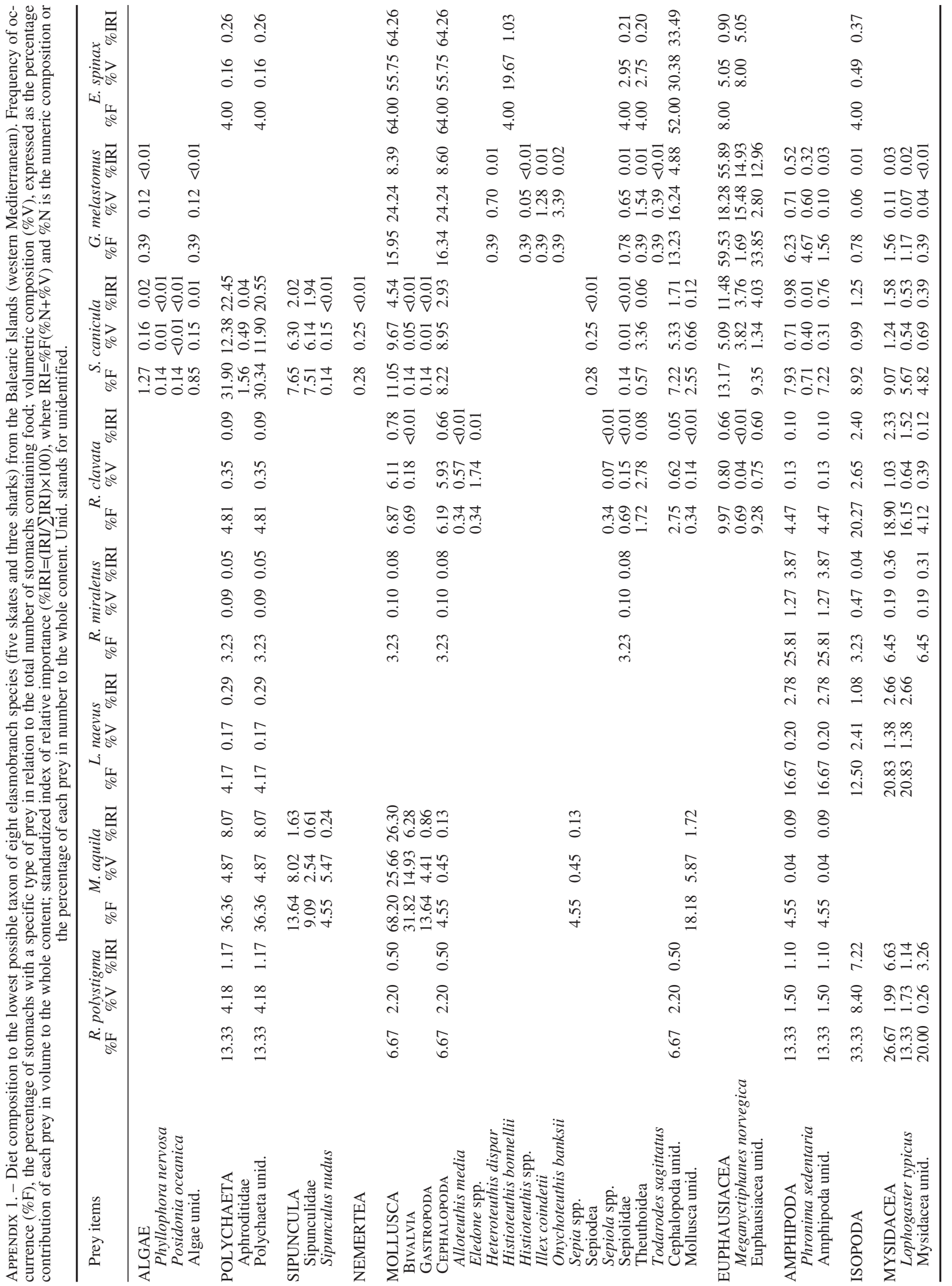




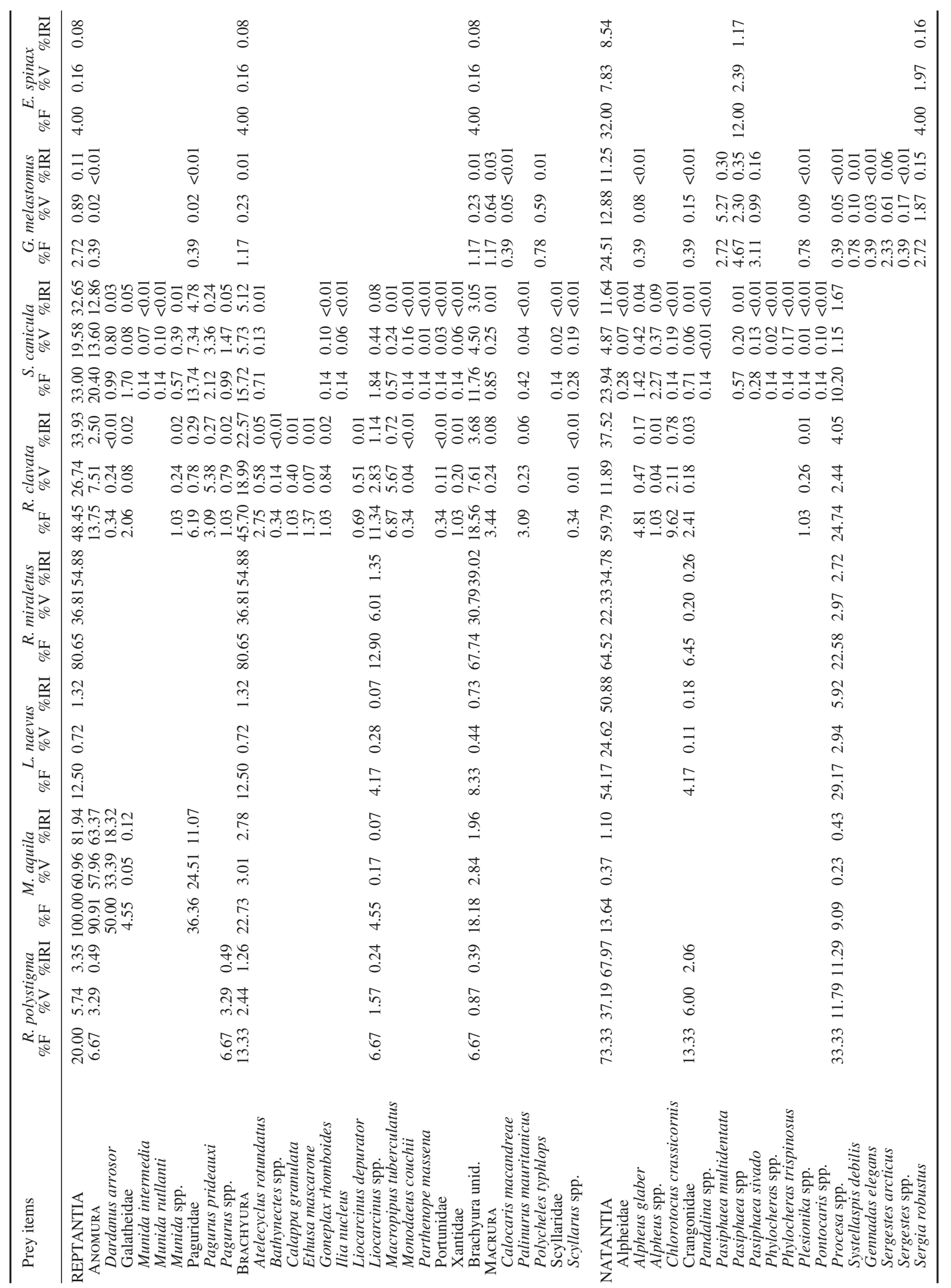




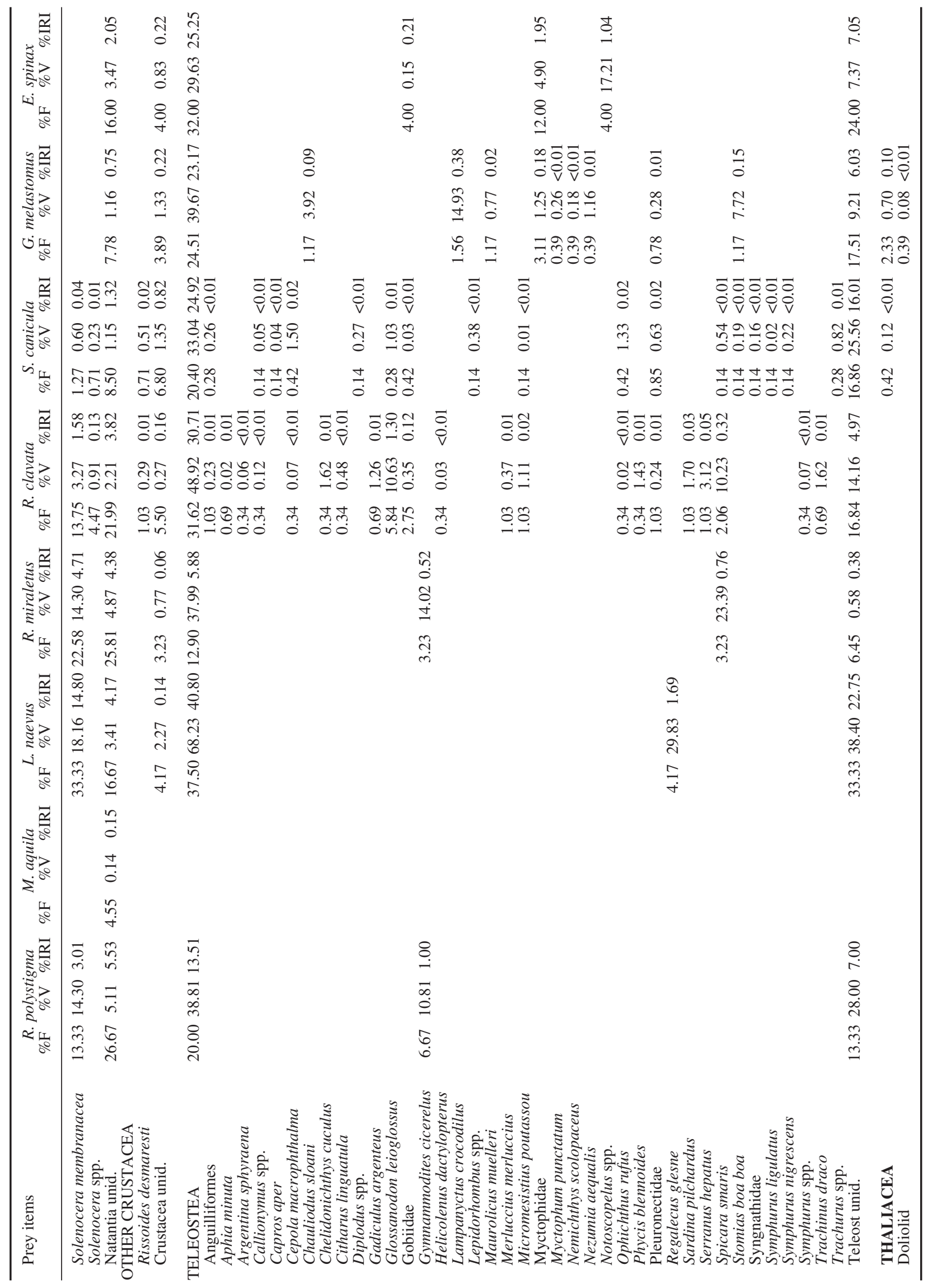


FEEDING ECOLOGY OF MEDITERRANEAN ELASMOBRANCHS • S5

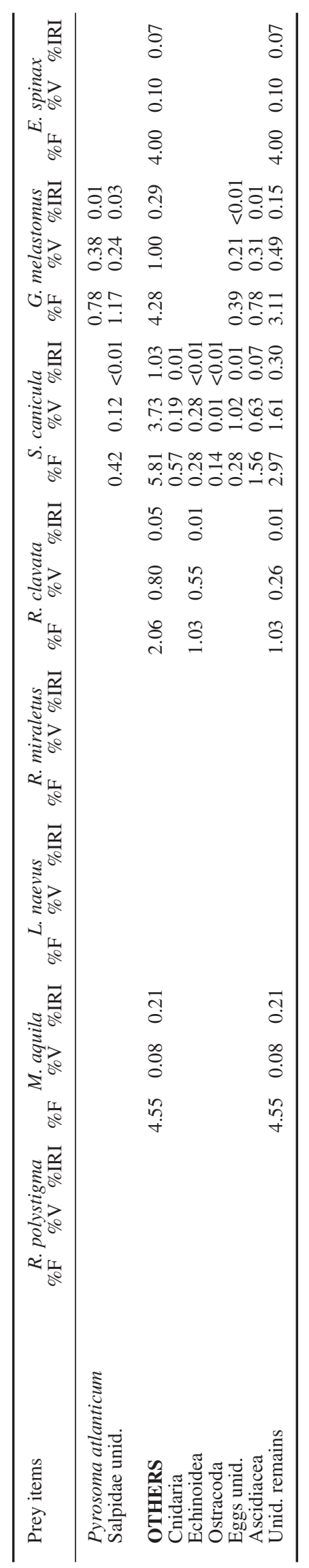

